\title{
РОЛЬ ІНТЕГРАЦІЇ В НАВЧАННІ АНГЛОМОВНОГО ЧИТАННЯ СТУДЕНТІВ ТЕХНІЧНИХ СПЕЦІАЛЬНОСТЕЙ
}

Литвиненко І. Ю. Роль інтеграції в навчанні англомовного читання студентів технічних спеціальностей.

Статтю присвячено вивченню методики навчання англійської мови студентів технічних спеціальностей, зокрема на рівні читання за допомогою засобів інтеграції. У статті розглянуто особливості мовленнєвої компетенції та міжнародні вимоги до ііі рівнів, а також деякі лінгводидактичні засоби підвищення рівня англомовного читання.

Ключові слова: англомовне читання, студенти технічних спеціальностей, мовленнєва компетенція, лінгводидактичні засоби, інтеграція.

Литвиненко И. Ю. Роль интеграции в обучении англоязычному чтению студентов технических специальностей.

Статья посвящена изучению методики обучения англоязычному чтению студентов технических специальностей, в частности на уровне чтения при помощи методов интеграции. В статье рассматриваются особенности речевой компетенции и международные требования к её уровням, а также некоторые лингводидактические средства повышения уровня англоязычного чтения.

Ключевые слова: англоязычное чтение, студенты технических специальностей, речевая компетенция, лингводидактические средства, интеграция.

Lytvynenko I. Yu. The role of integration in English reading teaching of the students of technical specialties.

The article represents the methods of English reading teaching of the students of technical specialities, particularly at the level of reading through integrative methods. The article discusses the features of a speech competence and international requirements of its levels, and some methodical ways of improving English reading. This English competence will help a technical specialist in his future professional activity.

Key words: English reading, students of technical specialties, speech competence, methodical ways, integration.

У статті «Мета і принципи державної інноваційної політики» закону України «Про інноваційну діяльність» констатовано: «Головною метою державної інноваційної політики є створення соціально-економічних, організаційних і правових умов ефективного відтворення, розвитку й використання науково-технічного потенціалу країни», а 3-поміж основних принципів державної інноваційної політики визначено [4] i забезпечення взаємодії науки, освіти, виробництва в розвитку діяльності, підтримку підприємництва в науково-виробничій галузі, а також здійснення заходів на підтримку міжнародної науково-технологічної кооперації, трансферу технологій, захисту вітчизняної продукції на внутрішньому ринку та іiі просування на зовнішній ринок. Тому логічно в Законі «Про інноваційну діяльність» окреслено питання підготовки кадрів у галузі інноваційної діяльності (осіб, що безпосередньо працюватимуть в галузі цієї міжнародної науково-технологічної кооперації та трансферу технологій). Звичайно, ці фахівці матимуть усі фахові 
компетенції, що відповідають означеним функціям (з-поміж яких і знання іноземних мов професійного спрямування).

Сучасними методистами приділяється увага предметній інтеграції у процесі вивчення іноземних мов різними спеціалістами, що передбачає набуття продуктивних зв'язків між різними навчальними предметами. Про таку інтеграцію зазначали ще А. Коменський та К. Ушинський, за їх концепціями працюють і сучасні дослідникиметодисти - О. Білик, К. Гуз, М. Іванчук, О. Савченко та ін. Особливості ж застосування міжпредметних зв'язків під час навчання іноземної мови нині досліджують О. Вєтхов, О. Заболотська, О. Зимовець, О. Каменський, І. Круківська, I. Кухта, С. Ніколаєва, О. Сіроштан, Н. Тимощук, О. Тинкалюк та ін.

При цьому недостатньо опрацьованими залишаються питання навчання іноземних мов (зокрема англійської) майбутніх технічних фахівців, що саме й представлятимуть інтереси Української держави на міжнародному рівні.

Тому метою статmi визначено розгляд процесу навчання англійської мови студентів технічних спеціальностей за допомогою засобів інтеграції, зокрема на рівні читання.

У доповіді «Тенденції в глобальній вищій освіті: відстеження академічної революції» (П. Альтбах, Л. Райсберг, Л. Рамблі), підготовленій для Всесвітньої конференції ЮНЕСКО з питань вищої освіти, 3-поміж тенденцій сучасного розвитку вищої освіти зазначаються й такі: глобалізація та інтернаціоналізація, глобальний академічний ринок, інформаційно-комунікаційні технології, зв’язок «університетпромисловість», модель «навчання-робота», підприємницька освіта [8], що передбачають відповідний рівень знань іноземних мов, зокрема англійської, а також інтегрованість у процесі як її навчання, так і використання.

Зазначимо, що популярний нині термін інтеграція (від лат. integrum - «ціле», integratio - «відновлення» [7, с. 412], також англ. integration «злиття, об'єднання» [1, c. 370]) загалом означає «поєднання, взаємопроникнення», тобто процес об'єднання певних елементів (частин) в ціле, взаємозближення й утворення взаємозв'язків, згуртування, об'єднання політичних, економічних, державних і громадських структур у межах регіону, країни, світу [5].

Тобто загальне значення «поєднання» передбачає певною мірою глобалізацію будь-якої галузі- економічної, культурної, політичної, освітньої. А оскільки глобалізація, безперечно, є нині прогресивним явищем (тенденцією до об'єднання світу в певних смислових просторах інтересів), то всі явища та процеси, що іiі супроводжують, можна назвати інноваційними.

У межах предметної царини нашого дослідження явище інтеграції в підготовці фахівця технічної сфери розглядається з двох позицій:

1) загальна орієнтація науки й освіти (що передбачає зокрема інноваційність, відповідність вимогам Болонського процесу);

2) засіб навчання в технічному закладі освіти (окреслює відповідні лінгводидактичні аспекти).

Запровадження інтеграційних принципів в освітньому процесі відбувається за такими чинниками:

а) глибока взаємопов'язаність усіх явищ і подій у світовому масштабі, що взаємозумовлено ідеєю єдності світу (пошуки світових універсалій виявлялися у спробах диференціації об'єктів і предметів за певними рубриками - види, форми, класи, типи тощо);

б) глибока взаємопов'язаність (інтеграція та диференціація) уже наявних наук - 
як предметних рубрик. У процесі формування світогляду інтегративний підхід передбачає відповідний взаємозв'язок таких складників:

- мотив, що спрямовує інтерес особистості на певний об'єкт. При цьому мотив може бути зумовлений як побутовими чинниками, так i професійними чи інтелектуальними;

- психологічна настанова, що передбачає наявність ідеї- своєрідного опредмечення мотиву, його конкретизації у словесній формі, яка, відповідно, постає безпосереднім джерелом активності процесу пізнання;

- знання, що зумовлені цим інтересом особистості щодо певного об'єкта. Ці знання можуть бути вже наявними, однак мотив вимагає збільшення кола таких знань. При цьому знання мають широкий «спектр»- від загальнолюдських до індивідуальних (етичних, історичних, релігійних, побутових тощо). Таким чином реалізується конструктивний інтерес.

Щодо останнього чинника варто зазначити, що у професійній підготовці фахівців технічних спеціальностей навчальний курс із вивчення іноземної мови $€$ міжпредметним, оскільки передбачає обов'язкове синтезування знань та умінь, і на відміну від елементів інтеграції, що наявні в навчальних комплексах традиційних професійно зорієнтованих дисциплін, елементами інтеграції постають комплекси міждисциплінарних знань та умінь. При цьому інтеграційний підхід в освітній підготовці фахівців технічних спеціальностей передбачає сукупність форм і методів, які характеризують процес і результат становлення професійної компетентності, супроводжуються зростанням системності знань, комплексності умінь студента, виражаються в теоретичній і практичній підготовленості та сприяють усебічному розвитку особистості.

Набуття знань під час професійної підготовки фахівців технічного профілю реалізується найбільш ефективно на основі інтеграції навчальних дисциплін у гуманістичній парадигмі освіти. Так, на основі вивчення основ філософії, а також історії та мови у студентів формується світогляд (у наш час - здебільшого інформаційний), пов'язаний зокрема і 3 майбутньою професійною діяльністю. Це сприяє розвитку їх загальної та інформаційної культури на основі інтеграції знань, умінь і набутої системи етнокультурних цінностей. Такий культурологічний підхід у професійній підготовці передбачає відбір знань та їх стратифікацію на основі інтеграції, а також поєднання в єдиний освітній простір у межах навчальних дисциплін.

Інтегрованість навчання передбачає залучення всіх наявних методик зі сфери вивчення інших дисциплін або професійної чи соціальної діяльності. У навчальних програмах цьому приділено відповідну увагу через фіксування міжпредметних зв'язків (у довідковій науковій літературі ці зв'язки тлумачаться як «взаємне узгодження навчальних програм, зумовлене системою наук і дидактичною метою» [2, c. 210]). Використання зв'язків між різними навчальними предметами посідає значну роль у визначенні змісту, методів та організації навчальної діяльності.

Отже, формування професійної компетентності, зокрема іншомовної, уже первинно має інтегративний, міжпредметний характер. Так, відомий педагогічний принцип «природовідповідності» (Г. Сковорода) передбачає зв'язок між вивченням предметів і законами природи, Я.-А. Коменський використовував знання природи, діяльності людини в навчальному матеріалі з вивчення рідної та латинської мов, зазначаючи при тому, що всі ці знання «постають 3 одного кореня - навколишньої дійсності, відзначаються взаємозв'язки, а тому повинні вивчатися у цих зв'язках» [6, 


\section{c. 26, c. 374$]$.}

М. Шмир зазначає, що систематичне використання інтегративного підходу в навчальному процесі позитивно змінює діапазон застосування знань і вмінь, сприяє формуванню широких пізнавальних інтересів. Міжпредметні зв'язки іноземної мови 3 іншими навчальними дисциплінами за своїм характером є змістовно-інформаційними та фактичними. Тобто, всебічне висвітлення їх на рівні фактів, подій сприяє узагальненню й систематизації знань, забезпечує підвищення конкурентоздатності та мобільності майбутніх фахівців [9, с. 223-224].

Зміст знань і їх форма вимагають у багатьох випадках саме відповідного підходу, оскільки за ізольованого чи повністю синтетичного підходу до змісту і форми знань іноді спостерігається їх спотворення, зокрема невідповідність форми і змісту. Зміст знань за інтегративного підходу вимагає інтегративного розуміння форми, а функція знань організує їх структуру, інтегративні ж функції передбачають структурування знань за певними принципами, причому поліфункціональність виявляється в усіх зв’язках, що дає більш повне уявлення про структуру системи.

Предметна інтеграція передбачає набуття продуктивних зв'язків між різними навчальними предметами, що виявляються у процесі навчання та залишаються у свідомості студента. Зокрема, іноземна мова вивчається на основі поєднання 3 навчальним матеріалом 3 української чи російської мов, що формує здатність до самостійного креативного навчання, тобто досягається через цілеспрямоване застосування засобів інтеграції. Також у процесі вивчення іноземної мови професійного спрямування залучаються зв'язки 3 технічними навчальними дисциплінами, що є профільними для відповідного фаху, а також соціальними, що формують світогляд майбутнього фахівця та допомагають зорієнтуватися в обставинах іншомовного спілкування та іноземної культури.

У цьому інтеграційному комплексі- поєднанні окремих предметів застосовуються такі форми навчання: усний опис картини, переклад 3 української чи російської мов (скажімо, текстів відомих пісень), використання фрагментів відомих художніх творів, кінофільмів тощо. Однак основним із них є читання, оскільки саме воно ознайомлює із новою інформацією, взятою з іншомовних сайтів Інтернету або зарубіжної науково-технічної літератури.

Методика вивчення англійської мови в технічних вишах передбачає застосування такого міждисциплінарного підходу в навчанні: залучаються елементи інтеграції за допомогою вироблених умінь і навичок з інших дисциплін. Наприклад, під час зіставлення певних явищ в англійській і рідній мовах виявляються подібні та відмінні елементи, і навіть елементарна звукова подібність у словах (на зразок тиsic, national, technical) викликає позитивні емоції i, як наслідок,- стимулювання у збагаченні словникового запасу.

Здавалося б, найбільш психологічно важкий елемент засвоєння англійської мови - орфоепічний - викликає інтерес у студентів, коли вони чують чітко вимовлені специфічні англійські монофтонги та дифтонги (скажімо, шиплячі звуки: butch, match, motion), а для порівняння - правильну літературну вимову українських шиплячих (Одещина, річчю, дощ), яка також для молоді буде новиною. Так, студенти розуміють, що орфоепічні закони в кожній мові $є$ непорушними та обов'язковими.

Труднощі ж, пов'язані з оволодінням англійською інтонацією, переборюються методичним шляхом - через визначення наголосу у слові і ритмічних звукових груп, дотримання шкали падіння і потрібного завершення на останньому наголошеному складі. Цей механізм ілюструється на прикладі української мови 3 подальшим 
порівнянням 3 англійською (речення інтонується спочатку українською, далі англійською мовами). Таке зіставлення допомагає уникнути вироблення інтерферем одиниць змішаного інтонування, а також дозволить сформувати навички роздільної вимови українських і англійських слів.

У такому сенсі навчання студентів читання іноземною (англійською) мовою в технічних ВНЗ із використанням інтеграційних засобів залежить від спільної діяльності викладачів іноземної, української мов, соціології, політології, історії, культурології та безпосередньо фахових (використовуються як джерело поповнення лексичного професійного запасу та ділових ігор), що передбачає встановлення взаємозв'язків між навчальними дисциплінами та спрямування їх на досягнення мети.

Варто акцентувати в контексті вище окресленого, що «Загальноєвропейські Рекомендації з мовної освіти» фіксують такі уміння та навички з читання іноземною мовою:

- розуміння автентичних текстів, пов'язаних із навчанням і спеціальністю; iз текстів підручників, науково-популярних i спеціалізованих журналів, джерел Інтернету;

- розуміння головної ідеї та знаходження необхідної інформації в неадаптованій фаховій економічній літературі;

- розуміння інструкції щодо функціонування устаткування та обладнання;

- розуміння графіків, діаграм та рисунків;

- уміння передбачати основну інформацію тексту за його заголовком та ілюстративним матеріалом, що супроводжує текст (прогнозувальне читання);

- здійснення ознайомлювального читання неадаптованих економічних текстів для отримання необхідної інформації;

- накопичування інформації з різних джерел для подальшого використання (на презентаціях, конференціях, дискусіях в академічному навчальному середовищі, а також у подальшій науковій роботі);

- здійснення навчального читання задля поповнення термінологічного тезаурусу;

- розуміння автентичної академічної та професійної кореспонденції (листи, факси, електронні повідомлення тощо);

- розуміння інформації рекламних матеріалів [3].

Отже, метод читання формує багато вмінь і навичок - від отримання інформації до іiї оброблення та використання.

Отже, нові політичні та соціально-економічні реалії сучасного ринку праці вимагають радикальних змін у галузі підготовки висококваліфікованих і конкурентоздатних професіоналів. Саме тому формування професійної іншомовної компетентності відбувається на засадах системної інтеграції традиційних і сучасних інформаційно-комунікаційних технологій у процесі опанування фахівцями технічного профілю іноземної мови професійного спрямування, зокрема за допомогою методу читання.

У подальшому плануємо більш конкретно розглянути методику використання методу читання під час вивчення англійської мови студентами технічних спеціальностей.

\section{Література}

1. Великий англо-український словник : [у новій редакції. 200000 слів, словосполучень, ідіоматичних виразів, прислів 'ів і приказок].- К. : Арій, 2008.784 с. 2. Гончаренко С. У. Український педагогічний словник / С. У. Гончаренко. К. : Либідь, 1997. - 376 с. 3. Загальноєвропейські Рекомендації з мовної освіти: вивчення, викладання, оцінювання / наук. ред. укр. вид. С. Ю. Ніколаєва. - К. : Ленвіт, 
2003. - 273 с. 4. Закон України «Про інноваційну діяльність» // Відомості Верховної Ради України (ВВР). - 2002. - № 36. - Ст. 266 (зі змінами, внесеними згідно із законами від 2002-2005, 2010-2012). 5. Інтеграція : [словникова стаття] [Електронний pecypc]. - Режим доступу : http://uk.wikipedia.org/wiki/ Інтеграція. 6. Коменский Я. А. Избранные педагогические сочинения: [в 2-х т.] / Я. А. Коменский. - М., 1982. - 648 с. 7. Латинско-русский словарь: [ок. 50000 слов. - 3-е изд., испр.]. - М. : Рус. яз., 1986. 840 с. 8. Тенденции в глобальном высшем образовании: мониторинг академической революции [Електронний ресурс] / Доклад, подготовленный для Всемирной конференции ЮНЕСКО по высшему образованию 2009 года; перевод Е. Н. Карачаровой. - Режим доступу : http://unesdoc.unesco.org/images/0018/001831/ $183168 \mathrm{e} / \mathrm{pdf}$ 9. Шмир М. Ф. Міжпредметний підхід у формуванні діяльнісної компетенції студентів у вивченні німецької мови / М. Ф. Шмир // Педагогічний альманах ; зб. наук. пр. / редкол. В. В. Кузьменко (голова) та ін. - Херсон : РІПО, 2011. - Випуск 12. - Частина 2. - 293 с. - С. 221-224.

\section{ФОРМУВАННЯ ПРОФЕСІЙНИХ ЦННОСТЕЙ КУРСАНТІВ МОРСЬКИХ НАВЧАЛЬНИХ ЗАКЛАДІВ ЗАСОБАМИ АНГЛІЙСЬКОЇ МОВИ (ЗА ПРОФЕСІЙНИМ СПРЯМУВАННЯМ)}

Ляшенко У. І. Формування професійних цінностей курсантів морських навчальних закладів засобами англійської мови (за професійним спрямуванням).

У статті розглядається проблема формування професійних цінностей курсантів морських навчальних закладів засобами англійської мови (за професійним спрямуванням); акцентується увага на етапах формування професійних цінностей; визначено найбільш сприятливі умови для ефективного формування професійних цінностей курсантів морських навчальних закладів освіти; доведено, що найбільш ефективному формуванню професійних цінностей курсантів сприятиме впровадження етапів їх формування на заняттях з англійської мови (за професійним спрямуванням).

Ключові слова: професійні цінності, психолого-педагогічні умови, курсант, етапи формування, морські навчальні заклади, англійська мова (за професійним спрямуванням).

Ляшенко У. И. Формирование профессиональных ценностей курсантов морских учебных заведений средствами английского языка (профессиональной направленности).

В статье рассматривается проблема формирования профессиональных ценностей курсантов средствами английского языка (профессиональной направленности); акцентируется внимание на этапах формирования профессиональных ценностей; установлены наиболее подходящие условия для эффективного формирования профессиональных ценностей курсантов морских учебных заведений; доказано, что наиболее эффективному формированию профессиональных ценностей курсантов будет способствовать реализация этапов её формирования на занятиях по английскому языку (профессиональной направленности).

Ключевые слова: профессиональные ценности, психолого-педагогические условия, курсант, этапы формирования, морские учебные заведения, английский язык (профессиональной направленности). 